\title{
Central Bank Independence, Financial Instability and Politics: New Evidence for OECD and Non-OECD Countries
}

\author{
Pistoresi B. ${ }^{1,3}$, Cavicchioli M. ${ }^{2} \&$ Brevini G. ${ }^{1}$ \\ ${ }^{1}$ Department of Economics “Marco Biagi”, University of Modena and Reggio Emilia, Modena, Italy \\ ${ }^{2}$ Department of Economics, University of Verona, Verona, Italy \\ ${ }^{3}$ RECent, Center for Economic Research, University of Modena and Reggio Emilia, Modena, Italy \\ Correspondence: Pistoresi Barbara, Department of Economics "Marco Biagi”, University of Modena and Reggio \\ Emilia, Viale Berengario 51, 41121, Modena, Italy. E-mail: barbara.pistoresi@unimore.it
}

Received: May 2, 2017

doi:10.5539/ijef.v9n7p179
Accepted: June 1, 2017

Online Published: June 20, 2017

\begin{abstract}
This paper analyses the determinants of a new index of central bank independence, recently provided by Dincer and Eichengreen (2014), using a large database of economic, political and institutional variables. Our sample includes data for 31 OECD and 49 non-OECD economies and covers the period 1998-2010. To this aim, we implement factorial and regression analysis to synthesize information and overcome limitations such as omitted variables, multicollinearity and overfitting. The results confirm the role of the IMF loans program to guide all the economies in their choice of more independent central banks. Financial instability, recession and low inflation work in the opposite direction with governments relying extensively on central bank money to finance public expenditure and central banks' political and operational autonomy is inevitably undermined. Finally, only for non-OECD economies, the degree of central bank independence responds to various measures of strength of political institutions and party political instability.
\end{abstract}

Keywords: central bank independence, economic, political and institutional determinants, multicollinearity, factor model, linear regression.

\section{Introduction}

Research on political macroeconomics during the last 20 years focused on factors affecting monetary policy and its performances. Several studies have examined the cause of monetary instability pointing out the key role of the Central Bank Independence (henceforth CBI) to account for differences in inflation rates among countries. It is widely documented, that a higher degree of $\mathrm{CBI}$ is associated with a lower inflation rate and that society reduces opposition to inflation and public pressure for an independent central bank (Cukierman, 2008, 2013, Alesina et al., 2011, Arnone \& Romelli, 2013). Even the mere adoption of a legal statute guaranteeing CBI significantly reduces inflationary expectations (Polillo \& Guillen, 2005). The balance between flexibility and credibility in monetary policymaking determines the equilibrium degree of $\mathrm{CBI}$ in a country. At the same time, the trade-off between costs and benefits in delegating the power to manage paper money may depend on many aspects of the economy and on its institutional framework (Alesina \& Grilli, 1995).

The recognition of this fact has encouraged a stream of literature that study the endogenous evolution of central banks. Alesina and Summers (1993) and Hayo (1998) suggest that after periods of hyperinflation, a "culture" in favour of price stability in "society" may arise such as there exists a positive relation between past inflation and the CBI. Posen (1995) and De Jong (2002) also discuss this issues of causality suggesting that different CBI reflects differences in preferences of population and financial lobbies for low and stable inflation and different distribution of power in the society.

Recent literature on the political economy approach has provided different explanations for why delegating to independent monetary institutions is more politically convenient in a context of multiple veto players. Most of the authors of this stream of literature expect that politically heterogeneous context (e.g., federal system, strong checks and balance, coalition or multiparty governments) should be more welcoming to independent monetary authorities (see Fernández-Albertos, 2015, for a survey). On the one hand, a larger political instability may increase the benefits to commitment; on the other hand, the high variability of the political environment may imply a lower 
ability to achieve commitment of monetary policy through delegation to an independent institution. Cukierman (1992) stresses that a high level of party political instability induces a larger level of independence, whereas the regime political instability has a negative effect on $\mathrm{CBI}$.

The international political economy literature suggests other driving forces that contribute to the institutional design of monetary authorities in open economies. Incentives to commitment to an independent central bank have to be inversely related to the degree of openness in the economy since, under flexible exchange rate, the terms of trade mechanisms is a "self-built-in check" on inflation temptations (Romer, 1993). Another crucial variable is the size of the worldwide common components in the business cycles of each country. It rests on the idea that, in the presence of worldwide common component in the business cycle, stabilization policy provided in one country has a positive spillover on the amount of stabilization policy provided abroad at no costs in terms of credibility, raising the incentives to commit (D'Amato \& Martina, 2005).

There are also external inducements that increase the degree of CBI. International institutions (e.g., IMF or World Bank) provide an important incentive to delegate to a CBI. In fact, they explicitly require countries to commit to particular set of policies and among these, a more independent central bank is often recommended. The participation in a monetary union also encourages countries to change the institutional design of monetary policy in view of greater price stability (Pistoresi et al., 2011, Dincer \& Eichengreen, 2014, Romelli, 2017).

Nowadays the "inflation problem" is that inflation is too low, not too high. Differently from the past, where the main goal of the central banks was to maintain an acceptable level of inflation, financial stability is now the new objective both in terms of macro-prudential supervision and to the traditional pursuit of macroeconomic stability (Masciandaro \& Romelli, 2015; and Alesina et al., 2011). Following the main financial crisis since 1998, e.g. South Korea in 1998, Turkey in 2001, the Dot-come bubble 1999-2000 and in particular the Great financial crisis in 2007-2008, many central banks turned to forward guidance and/or a variety of unconventional monetary policies, such as lending to banks (and sometimes even to nonbanks) in huge volume, and large-scale asset purchases ("quantitative easing") that is they use their balance sheets to affect market conditions (see De Haan \& Eijffinger, 2017). Some of these behaviours, in particular those associated with the expanded fiscal role of central banks, can be also associated with the weaknesses of political institutions. According to Buiter (2016), "the combination of these central bank dysfunctionalities with the rising tide of populist, anti-elite, anti-technocratic and anti-expert sentiment in the US and the EU is likely to result in an early and significant reduction in the degree of operational independence of North Atlantic central banks, even where such independence makes sense - in the design and conduct of monetary policy, narrowly defined".

Thus, since crises may induce an endogenous evolution of monetary institutions and incentive to undertake reforms, some important questions arise: has the CBI decreased since the financial crisis? Has the role of economic and political determinants of CBI changed? Are there differences among OECD and non-OECD economies with respect to these topics? The goal of this paper is to investigate these issues. In particular, it analyses the determinants of a new CBI index recently provided by Dincer and Eichengreen (2014), from a large set of economic, political and institutional variables.

Our sample includes data for 31 OECD and 49 non-OECD economies and covers the period 1998-2010. To this aim, we employ factor analysis as an appropriate statistical technique to deal with large amounts of data, as it retains a high power of data reduction and facilitate the design of aggregated variables. Moreover, it is possible to analyse the interrelations among a large list of indicators in order to understand their underlying structure, making it possible to reduce information into a small number of aggregated variables. Since factors can be saved and used in further analysis, this technique reduces the chance of double-counting highly similar attributes (multicollinearity) as well as possible biases from having redundant exogenous variables in regression (overfitting). In fact, we are then able to evaluate the relative importance of each aggregate variable (factor) on CBI in a linear regression framework. In other words, we can select determinants of CBI given a large amount of information coming from the initial database and, at the same time, avoid collinearity issues since correlated variables are already grouped in the factor analysis step.

Our results show no evidence of CBI decreasing after the Great financial crisis, but identify new relevant determinants with respect to the previous literature. In particular, we confirm a key role of the IMF loans program as an international constraint, which seems to guide all the economies in their choice toward independent central banks. Financial instability, recession and low inflation work in the opposite direction with governments relying extensively on central bank money to finance public expenditure. In this context, central banks' political and operational autonomy is inevitably undermined for the fulfilment of their policy objective of preserving price stability. Finally, the degree of CBI in non-OECD economies responds to various measures of 
strength of political institutions: the less is the strength of political institution, the higher is the incentive to delegate to an independent central bank, except for corruption. In fact, greater the level of corruption, higher is the incentive to delegate to an independent central bank. Non-OECD countries with more party political instability due to heterogeneous political contexts have a higher incentive to delegate to a more independent central bank. The delegation to an independent central bank is a way to facilitate the coexistence of actors with heterogeneous preferences within the executive, i.e. coalition or minority government, in particular when information asymmetries are presents, for example, between coalition government parties and the executive. Moreover, multiparty government are heavily dependent on the use of fiscal policy, and this increases the incentive to delegate in the hands of an independent institution (non-targetable) the monetary policy or unpopular policies maximising the probability to be re-elected.

The paper is organized as follows. In Section 2 we describe in detail the considered dataset. Section 3 presents the employed methodology and empirical results. Finally, Section 4 concludes.

\section{Data}

Indices of CBI are built using de jure or de facto measures of independence. The jure independence uses the central banks' statutes to obtain information on, among others, the independence of the governor of the central bank, its independence in policy formulation, its objective or mandate, and the limits on its lending to the public sector. The most used indices of legal (de jure) independence are those of Grilli et al. (1991) and Cukierman et al. (1992) (henceforth CWN). Recently, Romelli (2017) presents an index that incorporate the characteristics of both the measures of independence above. Finally, de facto indices associate the CBI to the autonomy of its governors, proxied by turnover rates of governors.

In this paper we examine the determinants of CBI using a new index recently provided by Dincer and Eichengreen (2014), (denoted by the authors as CBIW). It is based on CWN legal index, but for the period 1998-2010. On top of that, the CBIW is augmented by adding other aspects of the CBI (de facto criteria) emphasized by the subsequent literature (see page 219 in Dincer \& Eichengreen, 2014): limits on the reappointment of the governor, measures of provisions affecting (re)appointment of board members similar to those affecting the governor, restrictions on government representation on the board, and intervention of the government in exchange rate policy formulation.

Figure 1 shows an overall positive trend in the index CBIW (indicating greater independence) for both OECD and non-OECD countries over the entire period. The growth from 1998 to 2010 for the OECD group was 9.47\%, and for non-OECD group 9.73\%. For OECDs, the first increase regards years between 2000 and 2003, when the average rate rose from 0.59 to 0.63 . In these years some countries, like Iceland, Norway, Turkey and Estonia, registered reform processes inducing a higher level of CBI with respect to the average. After the 2007-2008 financial crisis, the index CBIW started a new growth for these advanced economies, while remain relatively stable for the other countries. For non-OECDs, the line shows a jump in the years 2003-2005, when the average CBIW increased from 0.45 to 0.47 . The countries that have seen biggest jumps are Venezuela, Iraq, Lithuania and Macedonia. The graph suggests that countries with lower level of development and democracy are investing in reform processes, probably due to international pressure (e.g. from IMF) to ensure financial and price stability. In conclusion, there is no evidence that the CBIW index has decreased after the Great financial crisis. Different authors, surveyed by De Haan and Eijffinger (2016), also observed the same.

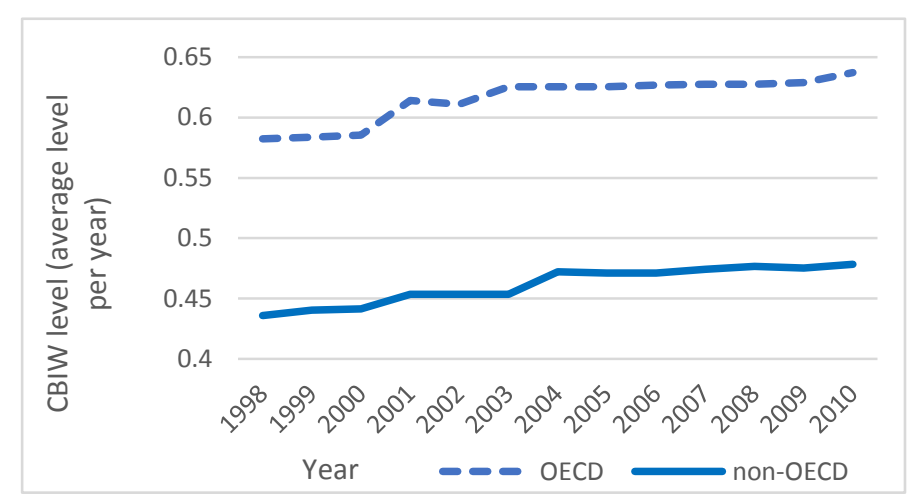

Figure 1. Plot of the values of CBIW index (from Dincer \& Eichengreen, 2014) for OECD (dashed line) and non-OECD (solid line) countries during the period 1998-2010 
The 47 variables used to investigate the determinants of CBI have been selected in line with recent literature on this topic (for a survey, see Fernández-Albertos, 2015). In particular, we consider the economic and political variables also used by Dincer and Eichengreen (2014) with some additional variables suggested by D'Amato et al. (2009). Moreover, we refer to the institutional variables used by Farvaque (2002), and Pistoresi et al. (2011). Our final sample includes data for 31 OECD and 49 non-OECD economies (see Note 1 for a detailed list of countries) and covers the years from 1998 to 2010.

The economic variables are the following: Inflation (measured by CPI index), RealGDP (GDP at constant prices), RealGDPpc (RealGDP per capita), Liquidity (M3 to GDP), Openness (import to GDP), IMFlending (as a ratio of GDP), CorrelationCycle (correlation between the country GDP growth and world GDP growth, i.e. the worldwide common component in the business cycle), Deficit (as a ratio of GDP), and Expenditure (government final expenditure to GDP). Those economic determinants are taken from IMF, World Bank and FED databases and are averaged over the considered period.

The political variables are taken from different sources. In particular, Stability (presence/absence of terrorism or political violence), Rule of Law (the confidence of the agents in societies rules, e.g. the quality of contracts enforcement and defense of property rights), GovEffectiveness (quality of public services, effectiveness of policies, credibility of government effort in the actuation of such policies), Accountability (perception of citizens to participate to the selection of their government members, freedom of speech and presence of free media), RegulatoryQ (ability of government to make laws and regulations to promote the development of the private sector), and Corruption (corruption of public institutions, magnitude of corrupting acts and the presence of "elite" and private interests at the head of state government) are taken from WGI database. Legal origin (civil or common-law system) and Transparency are obtained from Dincer and Eichengreen (2014). Finally, Democracy (the possibility to express different preferences on different political alternatives, the existence of constraints on the exercise of power by the executive, the guarantee of political and civil liberties) is taken from Polity IV database. Also these variables are averaged over the selected years.

The institutional variables are found in the DPI database of the World Bank, originally published by Beck et al. (2001). The database is divided into five groups of variables taken at the year 2010, which are the following: 1) Chief Executive variables, which are relevant to characterize the executive power: system (if presidential, assembly elected or parliamentary), yrsoffc (number of years in office), finittrm (presence of finite term in offce), yrcurnt (years left in current term), military (if the chief executive is a military officer), allhouse (control of all the houses by executive party); 2) Party variables in the legislature, which are relevant to the parties that make up the legislative power: numgov and numvote (number of seats and vote share of the government parties, respectively), totalseats (total seats of the parliament in the legislature), gov1seat and gov2seat (number of seats of the first and second government parties, respectively), numopp and oppvote (number of seats and vote share of the opposition parties, respectively), opp1 seat, opp2seat and opp3seat (number of seats of the first, second and third opposition parties, respectively), legelec and exelec (presence of legislative or executive elections); 3 ) Electoral rules: liec and eiec (indeces of legislative and executive competitiveness), mdmh (mean district magnitude), plurality and pr (plurality or proportional representation), housesys (in mixed electoral systems, which governs the majority or all the House seats); 4) Stability and checks and balance, which relates to the stability of the political system: tenlong and tenshort (longest and shortest tenure of a veto players), tensys (duration of democratic or autocratic system), checks (number of veto players); 5) Federalism, which relates to the state form: state (if local governments are elected). Finally, note that all the cited databases in this Section and their sources are detailed in Note 2.

\section{Results}

Given the extended literature suggesting a wide set of determinants for the CBI, the research methodology needs to find appropriate tools for dimension reduction and model selection. Thus, our large dataset is investigated at two different research stages. Firstly, we implement factor analysis to synthesize information and factors are identified such as variables are grouped to specify a particular aspect of the initial dataset. Secondly, linear parametric modelling is used to evaluate the relative importance of each factor as determinants of CBI index, avoiding limitations such as omitted variables, multicollinearity and overfitting.

\subsection{Factor Analysis}

The factors are identified following the recommended guidelines of Hair et al. (2014) and their number is selected in accordance to the Kaiser criterion of corresponding eigenvalues greater than one in modulus. Moreover, the cumulative explained variance of each selected factor is also reported and it is satisfactory.

The analysis of the component matrices in Tables 1 and 2 indicates the type of dimension captured. Table 1 
considers factors extracted from the economic and political groups. The first factor, named "political factor", mainly captures different measures of strength of political institutions, since it is highly positively correlated to the group of political variables (with correlation higher than 0.9): Rule of Law, GovEffectivness, Accountability, RegulatoryQ and Corruption. The second factor is only directly related to the degree of openness of the economy (with correlation higher than 0.7) and for this reason we label it as "openness factor". Finally, the third factor is directly related to the national deficit to GDP and indirectly related to the IMF lending to GDP, so we name it "financial factor" (with major correlation over 0.57).

Table 2 shows correlations between the institutional variables and the extracted factors. Particularly, the first and the second factors are positively related to characteristics of the parties that make up the legislative power. The "opposition factor" is directly related to the number of seats of the first-largest, second-largest and third-largest opposition parties (with correlation greater than 0.75). Moreover, it relates to the total number of seats of the opposition coalition and to the total seats of the parliament in the legislature. The "goverment factor" is directly related to the number of seats of the first-largest government party and to the total number of seats of the goverment (correlations are higher than 0.75). The third factor, named "electoral rules", concerns variables that are relevant for the electoral system: if countries have uninominal majority system or proportional representation and in mixed electoral systems (correlations over 0.66). The residual factor, named "chief executive factor", contains variables which are relevant to characterize the tenure and turnover of the executive power: how many years the chief executive has been in office and years left in current term (correlations are above 0.58).

Table 1. Extraction of factors from economic and political groups of variables.

\begin{tabular}{lccc}
\hline & political factor & openness factor & financial factor \\
\hline Trasparency & .789 & -.211 & -.187 \\
Inflation & -.510 & .069 & .153 \\
Openness & -.012 &. $\mathbf{7 1 6}$ & -.188 \\
Liquidity & .650 & -.016 & .024 \\
Deficit & -.053 & .578 & $\mathbf{. 5 8 6}$ \\
Expenditure & .548 & .079 & -.250 \\
RealGDPpc & .855 & .107 & .234 \\
RealGDP & .358 & -.495 & .397 \\
CorrelationCycle & -.017 & -.171 & .502 \\
IMFlending & -.272 & -.140 & -.573 \\
Stability & .745 & .397 & -.054 \\
Democracy & .708 & -.318 & -.294 \\
Rule of Law & $\mathbf{. 9 6 8}$ & .105 & .051 \\
GovEffectivness & $\mathbf{. 9 7 0}$ & .129 & .063 \\
Accountability & $\mathbf{. 9 1 4}$ & -.125 & -.154 \\
RegulatoryQ & $\mathbf{. 9 4 7}$ & .066 & -.048 \\
LegalOriginUK & .270 & -.530 & .336 \\
Corruption & $\mathbf{. 9 5 1}$ & .159 & .125 \\
Eigenvalue & 8.185 & 1.820 & 1.543 \\
Explained Variance & 45.474 & 10.113 & 8.574 \\
Cumulative Explained Variance & 45.474 & 55.587 & 64.610 \\
\hline
\end{tabular}

Note. The table reports correlations between factors and variables. Bold face enlights the highest correlations. Factors are extracted following Kaiser criterion (eigenvalues greater than one in modulus) and satisfactory cumulative explained variance. 
Table 2. Extraction of factors from institutional group of variables

\begin{tabular}{|c|c|c|c|c|}
\hline & opposition factor & government factor & electoral rules factor & chief executive factor \\
\hline system & 0.268 & -0.331 & 0.142 & -0.230 \\
\hline yrsoffc & -0.377 & 0.210 & 0.471 & 0.588 \\
\hline finittrm & 0.291 & -0.241 & -0.521 & -0.305 \\
\hline yrcurnt & -0.047 & 0.154 & -0.093 & -0.650 \\
\hline military & -0.075 & 0.551 & 0.179 & -0.189 \\
\hline allhouse & -0.256 & 0.489 & 0.045 & -0.184 \\
\hline numgov & 0.523 & 0.758 & 0.191 & -0.103 \\
\hline numvote & -0.146 & -0.213 & 0.646 & -0.400 \\
\hline numopp & 0.884 & 0.239 & -0.022 & 0.117 \\
\hline oppvote & 0.203 & -0.566 & 0.294 & -0.214 \\
\hline totalseats & 0.749 & 0.633 & 0.093 & 0.029 \\
\hline gov1seat & 0.415 & 0.808 & 0.125 & -0.111 \\
\hline gov2seat & 0.432 & 0.011 & 0.238 & 0.022 \\
\hline opp1seat & 0.772 & 0.304 & -0.104 & 0.122 \\
\hline opp2seat & 0.787 & 0.108 & 0.138 & 0.032 \\
\hline opp3seat & 0.618 & -0.035 & 0.182 & 0.034 \\
\hline legelec & 0.146 & -0.060 & -0.086 & 0.548 \\
\hline exelec & -0.015 & -0.015 & -0.071 & 0.367 \\
\hline liec & 0.429 & -0.563 & -0.237 & 0.244 \\
\hline eiec & 0.512 & -0.631 & -0.350 & -0.088 \\
\hline mdmh & -0.054 & -0.107 & 0.442 & 0.021 \\
\hline plurality & 0.011 & 0.429 & -0.676 & 0.121 \\
\hline $\mathrm{pr}$ & 0.330 & -0.256 & 0.659 & -0.125 \\
\hline housesys & 0.165 & -0.276 & 0.773 & -0.180 \\
\hline tenlong & -0.439 & 0.262 & 0.323 & 0.281 \\
\hline tenshort & -0.328 & 0.082 & 0.331 & 0.541 \\
\hline tensys & 0.409 & -0.412 & 0.275 & 0.198 \\
\hline checks & 0.376 & -0.503 & -0.227 & 0.263 \\
\hline state & 0.504 & -0.062 & 0.205 & 0.292 \\
\hline Eigenvalue & 5.476 & 4.492 & 3.501 & 2.374 \\
\hline Explained Variance & 18.884 & 15.491 & 12.074 & 8.187 \\
\hline Cumulative Explained Variance & 18.884 & 34.375 & 46.449 & 54.636 \\
\hline
\end{tabular}

Note. The table reports correlations between factors and variables. Bold face enlights the highest correlations. Factors are extracted following Kaiser criterion (eigenvalues greater than one in modulus) and satisfactory cumulative explained variance.

\subsection{Regression Analysis}

After having identified the relevant group of variables in factors, we aim at evaluating the relative importance of each factor as determinants of the CBI index. Therefore, we conduct linear regression analysis where the identified dimensions are the independent variables and the CBIW index is the dependent one.

The basic model refers to the following specification:

$$
C B I_{i}=b_{0}+\sum_{k} b_{1 k} P_{k}+u_{i}
$$

where $i$ is the country-index and $\mathrm{P}_{\mathrm{k}}$ is the $k$ th factor extracted from the economic and political groups of variables (see Table 1).

The augmented model refers to the following specification:

$$
C B I_{i}=b_{0}+\sum_{k} b_{1 k} P_{k}+\sum_{j} b_{2 j} F_{j}+u_{i},
$$

where $i$ is the country-index, $\mathrm{P}_{\mathrm{k}}$ and $\mathrm{F}_{\mathrm{j}}$ are the $k$ th factor extracted from the economic and political groups of variables (see Table 1) and the $j$ th factor extracted from the institutional group of variables (see Table 2), respectively. Results are shown in Table 3.

The financial factor defined by the national deficit and IMF lending enters negatively and significantly in all the specifications, i.e. in full sample models and in both OECD and non-OECD restricted models. Taking in mind the correlations between this factor and variables (seen in Table 1), we conclude that economies with more IMF 
lending retain more CBI. This evidence of external inducements to reform is in line with Abiad and Mody (2005), Dincer and Eichengreen (2014), Berggren et al. (2016) and Romelli (2017). It is also coherent with the current policy of IMF that controls the laws and regulations affecting autonomy, transparency, and governance at the central bank. The Fund pressures the economies benefiting from loans programs to reform their central banks toward greater independence, avoiding that their government interference can undermine the bank's autonomy and increase the risks associated with its operations. The strong estimated relevance of this variable reflects the importance of the IMF loans program in the considered period. In fact, the transition process in Central and Eastern Europe and the crises in emerging market economies led to an increase in the demand for IMF resources in the 1990s. Morever, the deep crises in Latin America and Turkey kept demand high for IMF resources in the early 2000s. Finally, IMF loans rose again since late 2008 with the global financial crisis. The IMF currently has programs with more than 50 countries around the world and has committed more than $\$ 325$ billion in resources to its member countries since the start of the global financial crisis.

Table 3 also suggests that economies with less deficit show a higher CBI (see also Table 1 for the relation between the financial factor and deficit). The commitment literature suggests that CBI should be a mechanism for signalling the anti-inflationary creditworthiness of governments to international investors. Countries with a weak public budget suffer from an excessive inflationary bias, which may increase the interest burden. Therefore, the benefits from commitment will tend to be larger (see, Cukierman, 1992). In this context, the expected sign for the deficit should be positive. However, our negative sign may be explained as follows. The central bank lending to the government, for example of short terms loans, has increased during the periods of financial instability (e.g. the Great 2007-2008 financial crises), since a number of governments have turned to central banks for money as government liabilities increased, tax revenues declined, and financing for fiscal imbalances from domestic and international capital markets was expensive or unavailable. Hence, during deep financial crises, recession and long period of low inflation (e.g. 2008-2012 period), society becomes accustomed to deficit monetization, thereby reducing opposition to deficit and public pressure for an independent central bank.

To summarize, IMF loans program works like an "external constraint" for the economies with high deficit and more incentive to monetize it, but the financial instability and recession in a period of low inflation (or deflation) work in the opposite direction with governments relying extensively on central bank money to finance public expenditure. Hence, central banks' political and operational autonomy is inevitably undermined for the fulfillment of their policy objective of preserving price stability.

Now we focus on the institutional factors. Dincer and Eichengreen (2014) state that "there is no evidence that countries with more robust political institutions strengthened the independence of their central banks, perhaps because the level of CBI was already high". This is true for OECD economies. However, Table 3 shows that the political factor (e.g. freedom of speech, trust in legal system) enters negatively and significantly in the specification for non-OECD countries: the less is the strength of political institution, the higher is the incentive to delegate to an independent central bank, except for corruption. In fact, greater the level of corruption, higher is the incentive to delegate to an independent central bank.

Furthermore, for non-OECD economies, the goverment factor also enters negatively and significantly. We recall that it only relates to the strength of the first-largest goverment party with respect to the total number of seats of the goverment coalition. This evidence, together with the results in Table 1, leads to the following consideration. Economies with strong first-largest goverment party have less incentive to delegate to an independent central bank. This is in line with the literature on the political economy approach to the CBI, (see Fernández-Albertos, 2015; and De Haan \& Eijffinger, 2017). It suggests that the delegation to an independent central bank is a way to facilitate the cohesistence of actors with heterogeneous preferences within the executive, i.e. coalition or minority goverment, in particular when information asymmetries are present, for example, between coalition goverment parties and the executive. Moreover, multiparty goverment are heavily dependent on the use of fiscal policy, and this increase the incentive to delegate in the hands of an independent institution (non-targetable) the monetary policy or unpopular policies maximising the probability to be re-elected.

Finally, the opposition, electoral rule and chief executive factors are not statistically significant, but they design a coherent picture reinforcing the comment above. The opposition factor describes the relative weight of the three-largest opposition parties to the first-largest goverment party, that is, the degree of political fragmentation and the possible heterogeneity of preferences with the risk that intra-party conflicts over policy threaten the stability of a goverment. The fragmentation is greater in countries with mixed electoral system, i.e. partly majority based and partly proportional based. In fact, they are generally characterized by a stricter control over the goverment made by the opposition (captured by the electoral factor). The party political instability may be more dramatic if the executive power is characterized by low tenure or high turnover. Leaders with shorter 
period in office are more likely to make opportunistic decisions that entails long-run costs to society that outweigh short-run benefits (captured by the chief executive factor).

Table 3. Linear regression analysis for the assessment of CBI determinants

\begin{tabular}{|c|c|c|c|c|c|c|}
\hline & \multicolumn{3}{|c|}{ Basic Model } & \multicolumn{3}{|c|}{ Augmented Model } \\
\hline & Full Sample & $O E C D$ & Non $O E C D$ & Full Sample & $O E C D$ & Non $O E C D$ \\
\hline \multirow[t]{2}{*}{ Constant } & $0.55 * * *$ & $0.53 * * *$ & $0.49 * * *$ & $0.56^{* * *}$ & $0.53 * * *$ & $0.48 * * *$ \\
\hline & $(0.00)$ & $(0.00)$ & $(0.00)$ & $(0.00)$ & $(0.00)$ & $(0.00)$ \\
\hline \multirow[t]{2}{*}{ Political factor } & 0.038 & 0.09 & -0.04 & -0.033 & 0.05 & $-0.15^{* *}$ \\
\hline & $(0.1)$ & $(0.08)$ & $(0.41)$ & $(0.36)$ & $(0.63)$ & $(0.02)$ \\
\hline \multirow[t]{2}{*}{ Openness factor } & 0.018 & 0.05 & 0.01 & 0.018 & 0.03 & 0.04 \\
\hline & $(0.43)$ & $(0.21)$ & $(0.75)$ & $(0.52)$ & $(0.59)$ & $(0.26)$ \\
\hline \multirow[t]{2}{*}{ Financial factor } & $-0.092 * * *$ & $-0.11 * * *$ & $-0.08 * *$ & $-0.075 * * *$ & $-0.09 * *$ & $-0.10^{*}$ \\
\hline & $(0.00)$ & $(0.00)$ & $(0.03)$ & $(0.01)$ & $(0.03)$ & $(0.06)$ \\
\hline \multirow[t]{2}{*}{ Opposition factor } & - & - & - & 0.054 & 0.04 & 0.02 \\
\hline & & & & $(0.16)$ & $(0.73)$ & $(0.66)$ \\
\hline \multirow[t]{2}{*}{ Government factor } & - & - & - & $-0.085^{* *}$ & -0.02 & $-0.13^{* * *}$ \\
\hline & & & & $(0.02)$ & $(0.86)$ & $(0.01)$ \\
\hline \multirow[t]{2}{*}{ Electoral Rules factor } & - & - & - & $0.06^{*}$ & 0.07 & 0.02 \\
\hline & & & & $(0.06)$ & $(0.46)$ & $(0.44)$ \\
\hline \multirow[t]{2}{*}{ Chief Executive factor } & - & - & - & 0.00 & -0.07 & 0.01 \\
\hline & & & & $(0.94)$ & $(0.24)$ & $(0.73)$ \\
\hline$N$ & 80 & 31 & 49 & 57 & 27 & 30 \\
\hline$R^{2}$ & 0.21 & 0.41 & 0.10 & 0.41 & 0.55 & 0.51 \\
\hline
\end{tabular}

Note. Estimated coefficients in table and relative $p$-values in parenthesis. The symbols *,**, *** denote significance level at $6 \%, 5 \%, 1 \%$, respectively.

\section{Conclusion}

In this paper we have implemented well-known statistical tools such as factorial and regression analysis to identify the determinants of a new CBI index from a large database of economic, political and institutional variables. The combination of these techniques has been used to synthesize information firstly and then to overcome limitations such as omitted variables, multicollinearity and overfitting. Our sample includes data for 31 OECD and 49 non-OECD economies and covers the period 1998-2010. The results confirm the role of the IMF loans program as an international constraint that seems to guide all the economies in their choice of independent ccntral banks. However, financial instability, recession and low inflation seem to work in the opposite direction with governments relying extensively on central bank money to finance public expenditure. Central banks' political and operational autonomy is inevitably undermined for the fulfillment of their policy objective of preserving price stability. Finally, for non-OECD economies, the degree of CBI responds to various measures of strength of political institutions and party political instability. Non-OECD countries with more party political instability due to heterogeneous political contexts have a higher incentive to delegate to a more independent central bank or, in other words, economies with strong first-largest goverment party have less incentive to delegate to an independent monetary authority. The importance of these political and institutional factors suggest that the adoption of an independent central bank should be understood not only in terms of economic efficiency but also in terms of political convenience, as also stressed by Fernández-Albertos (2015).

\section{References}

Abiad, A., \& Mody, A. (2005). Financial reform: What shakes it? What shapes it? American Economic Review, 95(1), 66-88. https://doi.org/10.1257/0002828053828699

Alesina, A. F., \& Grilli, V. (1995). The European Central Bank: reshaping monetary politics in Europe. In T. Persson \& G. Tabellini (Eds.), Monetary and Fiscal Policy (Vol. 1, pp. 247-277). Cambridge MA: The MIT Press.

Alesina, A. F., \& Summers, L. H. (1993). Central bank independence and macroeconomic performance: Some comparative evidence. Journal of Money, Credit and Banking, 25(2), 151-162. https://doi.org/10.2307/2077833 
Alesina, A. F., Stella, A., Friedman, B., \& Woodford, M. (2011). The Politics of Monetary Policy. Handbook of Monetary Economics, Ch. 8, 1000-1054. Amsterdam: North Holland.

Arnone, M., \& Romelli, D. (2013). Dynamic central bank independence indeces and inflation rate: A new empirical exploration. Journal of Financial Stability, 9(3), 385-398. https://doi.org/10.1016/j.jfs.2013.03.002

Beck, T., Clarke, G., Groff, A., Keefer, P., \& Walsh, P. (2001). New tools in comparative political economy: The database of political institutions. The World Bank Economic Review, 15(1), 165-176. https://doi.org/10.1093/wber/15.1.165

Berggren, N., Daunfeldt, S. O., \& Hellström, J. (2016). Does social trust speed up reforms? The case of central-bank independence. Journal of Institutional Economics, 12(2), 395-415. https://doi.org/10.1017/S1744137415000284

Buiter, W. (2016). Dysfunctional Central Banking. The End of Independent Central Banks or a Return to "Narrow Central Banking" - or Both?. Citi Research.

Cukierman, A. (1992). Central Bank Strategy, Credibility, and Independence: Theory and Evidence. Cambridge MA: The MIT Press.

Cukierman, A. (2008). Central Bank Independence and monetary policymaking institutions - Past, present and future. European Journal of Political Economy, 24, 722-736. https://doi.org10.1016/j.ejpoleco.2008.07.007

Cukierman, A. (2013). Monetary policy and institutions before, during, and after the global financial crisis. Journal of Financial Stability, 9(3), 373-384. http://dx.doi.org/10.1016/j.jfs.2013.02.002

Cukierman, A., Web, S. B., \& Neyapti, B. (1992). Measuring the independence of central banks and its effect on policy outcomes. The World Bank Economic Review, 6(3), 353-398. https://doi.org/10.1093/wber/9.2.335

D'Amato, M., \& Martina, R. (2005). Credibility and commitment of monetary policy in open economies. European Journal of Political Economy, 21, 872-902. https://doi.org/10.1016/j.ejpoleco.2004.11.006

D'Amato, M., Pistoresi, B., \& Salsano, F. (2009). On the determinants of central bank independence in open economies. International Journal of Finance \& Economics, 14(2), 107-119. https://doi.org/10.1002/ijfe.360

De Haan, J., \& Eijffinger, S. C. (2016). The politics of central bank independence. In R. Congleton, B. Grofman, \& S. Voigt (Eds.), Oxford Handbook of Public Choic. Oxford: Oxford University Press.

De Haan, J., \& Eijffinger, S. C. (2017). Central bank independence under threat? CEPR working paper No. 87.

De Jong, E. (2002). Why are price stability and statutory independence of central banks negatively correlated? The role of culture. European Journal of Political Economy, 18(4), 675-694. https://doi.org/10.1016/S0176-2680(02)00114-3

Dincer, N. N., \& Eichengreen, B. (2014). Central Bank Transparency and Independence: Updates and New Measures. International Journal of Central Banking, 10(1), 189-259.

Farvaque, E. (2002). Political determinants of central bank independence. Economics Letters, 77(1), 131-135. https://doi.org/10.1016/S0165-1765(02)00120-9

Fernández-Albertos, J. (2015). The politics of Central Bank independence. Annual Review of Political Science, 18, 217-237. https://doi.org/10.1146/annurev-polisci-071112-221121

Grilli, V., Masciandaro, D., \& Tabellini, G. (1991). Political and monetary institutions and public financial policies in the industrial countries. Economic Policy, 6(13), 342-392. https://doi.org/10.2307/1344630

Hair, J. F., Anderson, Jr R. E., Tatham, R. L., \& Black, W. C. (2014). Multivariate Data Analysis with Readings (7th ed.). MacMillan Publishing, New York.

Hayo, B. (1998). Inflation culture, central bank independence and price stability. European Journal of political Economy, 14(2), 241-263. https://doi.org/10.1016/S0176-2680(98)00006-8

Masciandaro, D., \& Romelli, D. (2015). Ups and downs. central bank independence from the great inflation to the great recession: Theory, institutions and empirics. Financial History Review, 22(3), 259-289. https://doi.org/10.1017/S0968565015000177

Pistoresi, B., Salsano, F., \& Ferrari, D. (2011). Political institutions and central bank independence revisited. Applied Economics Letters, 18(7), 679-682. http://dx.doi.org/10.1080/13504851.2010.485923

Polillo, S., \& Guillén, M. F. (2005). Globalization pressures and the state: The worldwide spread of Central Bank 
Independence. American Journal of Sociology, 110(6), 1764-1802. https://doi.org/10.1086/428685

Posen, A. S. (1995). Declarations are not enough: Financial sector sources of central bank independence. NBER Macroeconomics Annual, 10, 253-274. https://doi.org/10.1086/654279

Romelli, D. (2017). The political economy of reforms in central bank design: Evidence from a new dataset, Mimeo.

Romer, D. (1993). Openness and inflation: theory and evidence. Quarterly Journal of Economics, 108, 869-903. https://doi.org/10.2307/2118453

\section{Notes}

Note 1. OECD countries: Australia, Austria, Belgium, Canada, Denmark, Estonia, Finland, France, Germany, Greece, Hungary, Iceland, Ireland, Israel, Italy, Japan, Korea, Mexico, Netherland, New Zealand, Norway, Poland, Portugal, Slovakia, Slovenia, Spain, Sweden, Turkey, UK, and USA.

Non-OECD countries: Albania, Angola, Armenia, Azerbaijan, Belarus, Bhutan, Botswana, Bulgaria, Cambodia, Colombia, Croatia, Cyprus, El Salvador, Fiji, Georgia, India, Indonesia, Jamaica, Jordan, Kenya, Kyrgyz Republic, Lao Republic, Latvia, Lithuania, Macedonia, Malaysia, Mauritius, Moldova, Mongolia, Mozambique, Namibia, Nigeria, Oman, Papua New Guinea, Peru, Philippines, Romania, Russia, Singapore, South Africa, Sri Lanka, Syria, Tanzania, Thailand, Trinidad and Tobago, Uganda, United Arab Emirates, Venezuela, Zambia.

Note 2. Our final sample is constructed from the following databases:

International Monetary Fund (IMF), available at http://www.imf.org/en/Data;

World Bank Data, available at http://data.worldbank.org/;

Federal Reserve Data (FED), available at https://fred.stlouisfed.org/;

Worldwide Governance Indicators (WGI), available at http://info.worldbank.org/governance/wgi/index.aspx\#home;

Polity IV database, available at http://www.systemicpeace.org/inscrdata.html;

Database of Political Institutions (DPI), available at http://www.worldbank.org/en/research.

\section{Copyrights}

Copyright for this article is retained by the author(s), with first publication rights granted to the journal.

This is an open-access article distributed under the terms and conditions of the Creative Commons Attribution license (http://creativecommons.org/licenses/by/4.0/). 